\title{
A common founder for the 35delG GfB2 gene mutation in connexin 26 hearing impairment
}

L Van Laer, P Coucke, R F Mueller, G Caethoven, K Flothmann, S D Prasad, G P Chamberlin, M Houseman, G R Taylor, C M Van de Heyning, E Fransen, J Rowland, R A Cucci, R J H Smith, G Van Camp

\begin{abstract}
Fifty to eighty percent of autosomal recessive congenital severe to profound hearing impairment result from mutations in a single gene, GJB2, that encodes the protein connexin 26. One mutation of this gene, the 35delG allele, is particularly common in white populations. We report evidence that the high frequency of this allelic variant is the result of a founder effect rather than a mutational hot spot in GJB2, which was the prevailing hypothesis. Patients homozygous for the 35delG mutation and normal hearing controls originating from Belgium, the UK, and the USA were genotyped for different single nucleotide polymorphisms (SNPs). Four SNPs mapped in the immediate vicinity of $G J B 2$, while two were positioned up to $76 \mathrm{~kb}$ from it. Significant differences between the genotypes of patients and controls for the five SNPs closest to GJB2 were found, with nearly complete association of one SNP allele with the 35delG mutation. For the most remote SNP, we could not detect any association. We conclude that the $35 \mathrm{delG}$ mutation is derived from a common, albeit ancient founder.
\end{abstract}

(F Med Genet 2001;38:515-518)

Keywords: connexin 26; GFB2; 35delG; founder effect

Molecular Medicine Unit and Yorkshire

Regional DNA

Laboratory, St James's

University Hospital,

Leeds, UK

R F Mueller

$M$ Houseman

G R Taylor

J Rowland

Molecular

Otolaryngology

Research

Laboratories,

Department of

Otolaryngology, Head

and Neck Surgery,

Iowa City, Iowa, USA

S D Prasad

G P Chamberlin

R A Cucci

R J H Smith

Correspondence to:

Professor Van Camp,

gvcamp@uia.ua.ac.be

Revised version received 26 April 2001

Accepted for publication

3 May 2001 to the endolymph, leading to hearing impairment. The resultant hearing loss involves all frequencies, is of variable severity (from mild to profound) even within sibships, rarely progresses, and most frequently is symmetrical in the two ears..$^{6-8}$

To date, 48 recessive and seven dominant disease causing GFB2 mutations have been identified (R Rabionet, P Gasparini, X Estivill. Connexins and Deafness Homepage, http// www.iro.es/cx26deaf.html, March 2001). One mutation, the deletion of one guanosine residue from a stretch of six between nucleotide positions 30 and 35 ( $35 \mathrm{delG}$ ), which results in a frameshift and premature protein truncation at codon 13, is the most common deafness causing allelic variant of $G \mathcal{F B} 2$ in sporadic patients and autosomal recessive families from Italy, Spain, Portugal, France, UK, Israel, Lebanon, Tunisia, Algeria, New Zealand, and in white American families of northern and southern European origin. ${ }^{9-13}$

Carrier frequencies of the $35 \mathrm{del}$ G mutation have been determined in several countries (table 1), and in some populations this mutation is more frequent than the $\Delta \mathrm{F} 508$ cystic fibrosis mutation. However, in non-white populations, the $35 \mathrm{delG}$ mutation is either not found or is very rare, with other "common" mutations prevailing, like the $235 \mathrm{delC}$ in the Japanese and Koreans, ${ }^{14-16}$ the 167 delT in the Ashkenazi Jewish, ${ }^{17}{ }^{18}$ and the R143W mutation in an African village. ${ }^{19}$ Most investigators have assumed that the high frequency of the 35delG mutation reflects the presence of a mutational hot spot within GFB2,911 172021 but others have suggested a founder effect. ${ }^{13}$ To resolve the issue, we performed genotyping in the immediate vicinity of the GFB2 gene. From these data, we present evidence that the high frequency of the 35 delG $G \mathcal{F B} 2$ allelic variant in the white population is the result of a founder effect rather than a mutational hot spot.

\section{Subjects and methods}

SUBJECTS

In this study, the following subjects were genotyped: 35 Belgian, 30 British, and 49 American white patients with non-syndromic hearing impairment who were homozygous for the 35delG mutation, and 70 Belgian, 30 British, and 50 American white random normal hearing controls. The American control samples were screened and selected for the absence of the 35delG mutation. In the Belgian and British control samples, no 35delG genotyping was performed. 
Table 1 Carrier frequency of the 35delG mutation in various populations

\begin{tabular}{|c|c|c|c|c|}
\hline Population & $\begin{array}{l}\text { Subjects } \\
\text { tested }\end{array}$ & $\begin{array}{l}\text { Carriers } \\
35 \text { delG }\end{array}$ & $\begin{array}{l}\text { Carrier } \\
\text { frequency } \\
(\%)\end{array}$ & Reference \\
\hline \multicolumn{5}{|l|}{ Europe } \\
\hline Norway & 190 & 1 & 0.5 & 22 \\
\hline Denmark & 95 & 2 & 2.1 & 22 \\
\hline Estonia & 113 & 5 & 4.4 & 22 \\
\hline Germany & 200 & 4 & 2.0 & 22 \\
\hline UK & 119 & 0 & 0.0 & 22 \\
\hline Holland & 89 & 2 & 2.2 & 22 \\
\hline Belgium & 190 & 1 & 0.5 & 22 \\
\hline Belgium & 360 & 9 & 2.5 & 23 \\
\hline France (Brittany) & 96 & 1 & 1.0 & 22 \\
\hline France & 200 & 1 & 0.5 & 22 \\
\hline France & 68 & 0 & 0.0 & 9 \\
\hline France & 512 & 14 & 2.7 & 24 \\
\hline Bulgaria & 157 & 1 & 0.6 & 22 \\
\hline Czech Republic & 195 & 4 & 2.1 & 22 \\
\hline Slovenia & 182 & 1 & 0.5 & 22 \\
\hline Italy (Sardinia) & 116 & 4 & 3.4 & 22 \\
\hline Italy & 255 & 8 & 3.1 & 22 \\
\hline Italy & 150 & 6 & 4.0 & 12 \\
\hline Spain & 200 & 5 & 2.5 & 22 \\
\hline Spain & 130 & 3 & 2.3 & 22 \\
\hline Portugal & 179 & 4 & 2.2 & 22 \\
\hline Malta & 144 & 4 & 2.8 & 22 \\
\hline Greece & 400 & 12 & 3.0 & 22 \\
\hline Greece & 395 & 14 & 3.5 & 25 \\
\hline Turkey & 150 & 4 & 2.7 & 22 \\
\hline \multicolumn{5}{|l|}{ North America } \\
\hline White Americans & 173 & 1 & 0.6 & 17 \\
\hline White Americans & 100 & 1 & 1.0 & 26 \\
\hline White Americans & 96 & 2 & 2.0 & 11 \\
\hline White Americans & 560 & 14 & 2.5 & 27 \\
\hline African Americans & 173 & 0 & 0.0 & 17 \\
\hline African Americans & 190 & 0 & 0.0 & 22 \\
\hline Asian Americans (Indian, Japanese, Koreans) & 53 & 0 & 0.0 & 17 \\
\hline Ashkenazi Jewish Americans & 551 & 4 & 0.7 & 17 \\
\hline \multicolumn{5}{|l|}{ Other populations } \\
\hline Egyptians & 95 & 0 & 0.0 & 22 \\
\hline Arabs & 58 & 1 & 1.7 & 22 \\
\hline Koreans & 100 & 1 & 1 & 15 \\
\hline
\end{tabular}

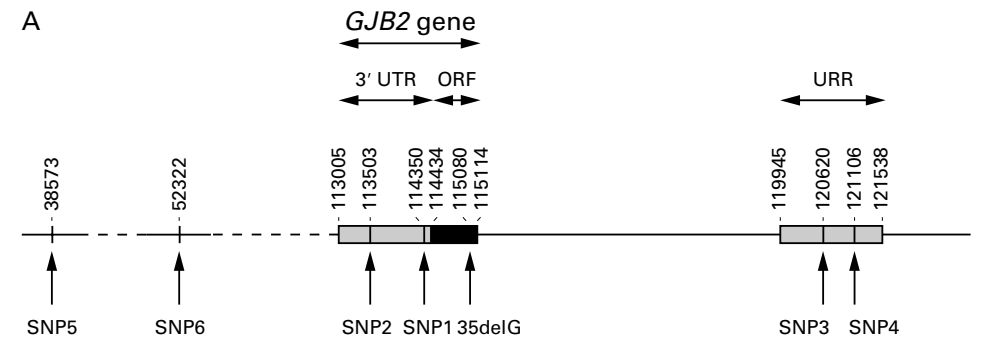

\begin{tabular}{l|l|l} 
B SNP & Distance to 35delG (bp)
\end{tabular}

SNP 1731

SNP 21578

SNP 35541

SNP $4 \quad 6027$

SNP 576508

SNP 6 62759

Figure 1 (A) Positions of the SNPs relative to the GfB2 gene. The GFB2 open reading frame $(O R F)$ is represented by the black box. The $3^{\prime} U T R$ and the URR are represented by shaded boxes. The borders of the ORF, UTR, and URR, the positions of the six SNPs, and the 35 del $G$ mutation are indicated with their respective nucleotide numbers derived from the genomic sequence of clone RP11-26474 (Genbank accession number AL138688). (B) The distance from each SNP to the 35 del G mutation in the GFB2 gene (given in bp).

SNP IDENTIFICATION

To identify SNPs (single nucleotide polymorphisms) in regions adjacent to the GFB2 gene, the 3'UTR (untranslated region, Genbank accession number M86849), and the URR (upstream regulatory region, Genbank accession number AF091526) were sequenced in six 35 delG carriers. Four SNPs were discovered, two in the 3'UTR (SNP 1 and 2) and two in the URR (SNP 3 and 4). The relative positions of the SNPs with regard to the GFB2 gene are depicted in fig 1, where the SNPs are placed on the complete nucleotide sequence of clone RP11-264J4 (Genbank accession number AL138688). Several SNPs more distant from the GFB2 gene were chosen from the SNP Consortium LTD (http://snp.cshl.org/) and analysed in random subjects. Two informative SNPs, SNP 5 (TSC1102325) and SNP 6 (TSC0127952), were selected for further analysis and positioned on the nucleotide sequence of clone RP11-264J4 (fig 1).

\section{SNP ANALYSIS}

SNP analysis was performed using the ABI Prism SNaPshot ddNTP Primer Extension Kit (ABI) according to the manufacturer's guidelines with minor modifications. PCR was performed using standard conditions and the primers and annealing temperatures listed in table 2. PCR products were treated with 0.164 $\mathrm{U} / \mu \mathrm{l}$ shrimp alkaline phosphatase (Promega) and $0.164 \mathrm{U} / \mu \mathrm{l}$ exonuclease I (New England Biolabs) for one hour at $37^{\circ} \mathrm{C}$, followed by the deactivation of the enzymes for 15 minutes at $72^{\circ} \mathrm{C}$. SNaPshot thermal cycling was performed with the respective $\mathrm{SNaPshot}$ primer (table 2), the matching PCR product, and the SNaPshot Ready Reaction Premix for 25 cycles of 10 seconds at $96^{\circ} \mathrm{C}$ denaturation, five seconds at $50^{\circ} \mathrm{C}$ annealing, and 30 seconds at $60^{\circ} \mathrm{C}$ extension. SNaPshot products were dephosphorylated by incubation at $37^{\circ} \mathrm{C}$ (one hour) with $0.15 \mathrm{U} / \mu \mathrm{l}$ calf intestine alkaline phosphatase (Gibco BRL Life Technologies). The enzyme was deactivated as described above and $\mathrm{SNaPshot}$ products were analysed on an ABI3100 automated DNA sequencer (ABI).

STATISTICAL ANALYSIS

Differences between groups were tested with $\chi^{2}$ statistics, if at least $80 \%$ of the expected frequencies exceeded 5 and all the expected frequencies exceeded 1 . If the expected values did not meet the criteria mentioned above, the numbers of the two least frequent alleles were added and Yates's correction for continuity for two by two tables was used. If the expected values of the two by two table still did not meet the criteria mentioned above, Fisher's exact test was used. Both the $\chi^{2}$ test and Fisher's exact test were calculated using the SigmaStat 2.0 software (Jandel Corporation). All $\mathrm{p}$ values were taken to be significant at $<0.05$.

\section{Results}

In order to determine whether the high frequency of the 35delG allele variant of $G \mathcal{F B 2}$ is the result of a mutational hot spot or a founder effect, SNPs adjacent to (SNPs 1 to 4 , fig 1) and more distant from (SNP 5 and 6, fig 1) GfB2 were analysed. Table 3 summarises the genotypes observed in this study. SNP 1 is very informative and results, even with small sample numbers, in significantly different genotypes for controls and patients. SNPs 2 and 3 are less informative, as the allele that is linked to 35delG (G for SNP 2 as well as for SNP 3) is also the most frequent allele in the 
Table 2 PCR and SNaPshot primers

\begin{tabular}{|c|c|c|c|c|}
\hline$S N P$ & Primer & Primer sequence & $\begin{array}{l}\text { Annealing } \\
\text { temperature } \\
\left({ }^{\circ} \mathrm{C}\right)\end{array}$ & $\begin{array}{l}\text { Length of } \\
\text { PCR product } \\
(b p)\end{array}$ \\
\hline SNP 1 & $\begin{array}{l}\mathrm{F} \\
\mathrm{R} \\
\text { SNaPshot }\end{array}$ & $\begin{array}{l}\text { aggcactggtaactttgtcc } \\
\text { gtgtctggaatttgcatcctgc } \\
\text { agctgtcaaggctcagtcgc }\end{array}$ & 59 & 589 \\
\hline SNP 2 & $\begin{array}{l}\mathrm{F} \\
\mathrm{R} \\
\text { SNaPshot }\end{array}$ & $\begin{array}{l}\text { caatgctattcttgacaacagg } \\
\text { ccacgttaaaggtgaacattgg } \\
\text { acctctttaaatcagcgttctttcc }\end{array}$ & 59 & 901 \\
\hline SNP 3 & $\begin{array}{l}\mathrm{F} \\
\mathrm{R} \\
\text { SNaPshot }\end{array}$ & $\begin{array}{l}\text { ctgtgtgatgttggctagtcg } \\
\text { gacaccacagtgagttttcc } \\
\text { ctgccctagaggagtcctgagcctacttgg }\end{array}$ & 56 & 676 \\
\hline SNP 4 & $\begin{array}{l}\mathrm{F} \\
\mathrm{R} \\
\text { SNaPshot }\end{array}$ & $\begin{array}{l}\text { gcttaggatagtactgctgc } \\
\text { cacggtgccattccatcagg } \\
\text { ctcattgacgtgcagagactgaccagatagagaag }\end{array}$ & 56 & 502 \\
\hline SNP 5 & $\begin{array}{l}\mathrm{F} \\
\mathrm{R} \\
\text { SNaPshot }\end{array}$ & $\begin{array}{l}\text { ctgagtaccaatctcaccac } \\
\text { tgcacagggataataaccgc } \\
\text { gggcccttaaacatgaggc }\end{array}$ & 56 & 230 \\
\hline SNP 6 & $\begin{array}{l}\mathrm{F} \\
\mathrm{R} \\
\text { SNaPshot }\end{array}$ & $\begin{array}{l}\text { taacaaggcctccaagtgac } \\
\text { gcttgccatcaagaaaggag } \\
\text { tcagcgtcatctctttggactgca }\end{array}$ & 55 & 381 \\
\hline
\end{tabular}

general population. However, when using larger sample numbers even these less informative SNPs show significant differences between controls and patients. SNP 4 is informative, giving significant differences even when using smaller sample numbers. SNP 6, which is approximately $63 \mathrm{~kb}$ away from the GFB2 gene, only shows significant differences between patients and controls in the total test population (fig 1, table 1). For SNP 5, which is the most remote SNP we investigated (approximately $76 \mathrm{~kb}$ away from $G \mathcal{F B} 2$, fig 1), no significant association with the $35 \mathrm{delG}$ mutation could be found. We conclude that the high frequency of the $35 \mathrm{delG}$ mutation in GFB2 is the result of a founder effect.

The 35delG mutation must have arisen many centuries ago as haplotype sharing is observed only in a small region. On the basis of the recombination frequency of a more distant SNP, we can estimate the age of the $35 \mathrm{delG}$ mutation. From one generation to the next, the probability of having a recombination between a gene and a nearby marker is equal to the recombination fraction $\theta$. In one generation, a fraction $\theta$ of all sibs will have a recombination and a fraction 1- $\theta$ will not. After $\mathrm{N}$ generations, the fraction of descendants that has no recombination equals $(1-\theta)^{\mathrm{N}}$. When examining SNP 6 in the total test population and assuming A was the allele associated with the $35 \mathrm{delG}$ mutation in the founder, 161 out of 224 chromosomes showed no recombination in a region of approximately $63 \mathrm{~kb}$ (assumed to correspond to $\theta=0.00063$ ). Consequently, the $35 \mathrm{delG}$ mutation is estimated to be about 500 generations, or approximately 10000 years old. As we do not know the true recombination frequency of this region, it should be emphasised that this calculation represents no more than a rough estimation, and that the range of error for this calculation is undoubtedly large.

\section{Discussion}

In this study, we show that the high frequency of the 35delG mutation is the result of a founder effect rather than a mutational hot spot, although the latter hypothesis has been favoured by most authors. ${ }^{911} 172021$ It has been argued that the deletion of one $\mathrm{G}$ from a stretch of six could have arisen frequently through polymerase slippage or the presence of a chi consensus motif in the immediate vicinity. ${ }^{911} \mathrm{~A}$ strong argument for a mutational hot spot is certainly the presence of this mutation in several geographically and ethnically distinct populations. $^{21}$ However, its absence or low prevalence in other ethnic groups, such as Asians,${ }^{1415}$ argues against this hypothesis.

Morell et $a l^{17}$ have shown that several different haplotypes surround the $35 \mathrm{delG}$ mutation, ${ }^{17}$ another strong argument in favour of a mutational hot spot. Their study considered an interval of $2 \mathrm{cM}$, while we have focused on a region of less than $70 \mathrm{~kb}$ or more than $95 \%$ smaller. As we have shown, the $35 \mathrm{delG}$ mutation is ancient and therefore haplotype sharing will be observed only in a very small chromosomal interval.

The age of the mutation further explains its widespread occurrence across Europe, the Mediterranean region, and the United States. Possibly, the mutation originated somewhere in the Middle East and was spread throughout Europe along the two Neolithic population movement routes. The first route followed the coast of the Mediterranean sea to Italy and Spain, while the other followed the Danube and Rhine valleys to northern Europe. The 35delG mutation would have been brought to the United States by emigration from Europe.

Table 3 Results of the SNP analysis

\begin{tabular}{|c|c|c|c|c|c|c|c|c|c|c|c|c|c|}
\hline \multirow[b]{2}{*}{$S N P$} & \multirow[b]{2}{*}{ Genotype } & \multicolumn{3}{|l|}{ Belgian } & \multicolumn{3}{|l|}{ British } & \multicolumn{3}{|c|}{ American } & \multicolumn{3}{|l|}{ Total } \\
\hline & & Patient & Control & $p$ & Patient & Control & $p$ & Patient & Control & $p$ & Patient & Control & $p$ \\
\hline \multirow[t]{3}{*}{ SNP 1} & $\mathrm{CC}$ & 0 & 47 & \multirow[t]{3}{*}{$<0.001$} & 0 & 18 & \multirow[t]{3}{*}{$<0.001$} & 0 & 31 & \multirow[t]{3}{*}{$<0.001$} & 0 & 96 & \multirow[t]{3}{*}{$<0.001$} \\
\hline & $\mathrm{CT}$ & 0 & 13 & & 2 & 12 & & 2 & 18 & & 4 & 43 & \\
\hline & $\mathrm{TT}$ & 33 & 1 & & 27 & 0 & & 45 & 1 & & 105 & 2 & \\
\hline \multirow[t]{3}{*}{ SNP 2} & GG & 31 & 20 & \multirow[t]{3}{*}{0.014} & 27 & 24 & 0.025 & 47 & 43 & \multirow[t]{3}{*}{0.013} & 105 & 87 & \multirow[t]{3}{*}{$<0.001$} \\
\hline & GA & 0 & 5 & & 0 & 6 & & 0 & 7 & & 0 & 18 & \\
\hline & $\mathrm{AA}$ & 0 & 0 & & 0 & 0 & & 0 & 0 & & 0 & 0 & \\
\hline \multirow[t]{3}{*}{ SNP 3} & GG & 33 & 29 & \multirow[t]{3}{*}{0.053} & 29 & 25 & 0.052 & 49 & 41 & \multirow[t]{3}{*}{0.003} & 111 & 95 & \multirow[t]{3}{*}{$<0.001$} \\
\hline & GA & 0 & 5 & & 0 & 5 & & 0 & 9 & & 0 & 19 & \\
\hline & $\mathrm{AA}$ & 0 & 0 & & 0 & 0 & & 0 & 0 & & 0 & 0 & \\
\hline \multirow[t]{3}{*}{ SNP 4} & $\mathrm{TT}$ & 31 & 22 & \multirow[t]{3}{*}{0.008} & 28 & 20 & $<0.001$ & 48 & 35 & \multirow[t]{3}{*}{$<0.001$} & 107 & 77 & \multirow[t]{3}{*}{$<0.001$} \\
\hline & $\mathrm{TG}$ & 0 & 6 & & 0 & 10 & & 0 & 14 & & 0 & 30 & \\
\hline & GG & 0 & 0 & & 0 & 0 & & 0 & 0 & & 0 & 0 & \\
\hline \multirow[t]{3}{*}{ SNP 5} & GG & 26 & 21 & \multirow[t]{3}{*}{0.611} & 22 & 20 & 0.472 & 35 & 31 & \multirow[t]{3}{*}{0.613} & 83 & 72 & \multirow[t]{3}{*}{0.358} \\
\hline & GA & 6 & 8 & & 5 & 10 & & 13 & 13 & & 24 & 31 & \\
\hline & AA & 2 & 2 & & 1 & 0 & & 1 & 4 & & 4 & 6 & \\
\hline \multirow[t]{3}{*}{ SNP 6} & GG & 6 & 5 & \multirow[t]{3}{*}{0.072} & 6 & 3 & 0.431 & 3 & 6 & \multirow[t]{3}{*}{0.224} & 15 & 14 & \multirow[t]{3}{*}{0.019} \\
\hline & GA & 10 & 17 & & 6 & 13 & & 17 & 22 & & 33 & 52 & \\
\hline & $\mathrm{AA}$ & 19 & 9 & & 17 & 13 & & 28 & 22 & & 64 & 44 & \\
\hline
\end{tabular}


The low carrier frequency seen in other populations, for example, in the Korean and Arab population, could also have originated from the same founder. On the other hand, however, it cannot be excluded that the 35 delG mutation has arisen on more then one occasion.

The reason for the high frequency of 35delG remains to be elucidated. By comparison, the $\Delta$ F508 cystic fibrosis mutation is by far the best known and studied ancient mutation. Its frequency varies in different populations and estimates of age of origin of the mutation range, from 2940 to 52000 years, depending on the methods used..$^{28}{ }^{29}$ It has been postulated that $\Delta \mathrm{F} 508$ carriers have an increased resistance to chloride secreting diarrhoea resulting in selective advantage for heterozygous carriers. ${ }^{30}$ At present, it is not known whether the carrier status for a mutation in $G \mathcal{F B} 2$ is associated with increased reproductive fitness.

The authors wish to thank Dr Rudy D'Hooghe for statistical advice, Drs Declau, De Meirleir, Goffart, Govaerts, Haentjens, Janssens, Lissens, Mansbach, Messiaen, Mortier, Offeciers, Raes, Van de Heyning, van den Ende, Verstreken, and Veryser for samples from congenital hearing impaired patients, and Sandra Willocx for 35delG genotyping. This study was supported by grant G.0277.01 from the FWO (Flemish Fonds voor Wetenschappelijk Onderzoek) and grant RO1-DC02842 from the NIDCD (RJHS).
positions with the FWO.

1 Morton NE. Genetic epidemiology of hearing impairment. Ann NY Acad Sci 1991;630:16-31.

2 Marazita ML, Ploughman LM, Rawlings B, Remington E Arnos KS, Nance WE. Genetic epidemiological studies of early-onset deafness in the U.S. school-age population. $A m$ 7 Med Genet 1993;46:486-91.

3 Gasparini P, Estivill X, Volpini V, Totaro A, Castellvi-Bel S, detto M, Stanziale P, Zelante L, Mansfield ES, Sandkuijl L, Surrey S, Fortina P. Linkage of DFNB1 to non-syndromic neurosensory autosomal-recessive deafness in Mediterranean families. Eur f Hum Genet 1997;5:83-8.

4 Kelsell DP, Dunlop J, Stevens HP, Lench NJ, Liang JN, Parry G, Mueller RF, Leigh IM. Connexin 26 mutations in hereditary non-syndromic sensorineural deafness. Nature 1997;387:80-3.

5 Denoyelle F, Lina-Granade G, Plauchu H, Bruzzone R, Chaib H, Levi-Acobas F, Weil D, Petit C. Connexin 26 gene linked to a dominant deafness. Nature 1998;393:319gene

6 Cohn ES, Kelley PM, Fowler TW, Gorga MP, Lefkowitz DM, Kuehn HJ, Schaefer GB, Gobar LS, Hahn FJ, Harri DJ, Kimberling WJ. Clinical studies of families with hearing loss attributable to mutations in the connexin 26 gene (GJB2/DFNB1). Pediatrics 1999;103:546-50.

7 Denoyelle F, Marlin S, Weil D, Moatti L, Chauvin P, Garabedian EN, Petit C. Clinical features of the prevalent form of childhood deafness, DFNB1, due to a connexin-26 gene defect: implications for genetic counselling. Lancet 1999;353:1298-303.

8 Murgia A, Orzan E, Polli R, Martella M, Vinanzi C, Leonardi E, Arslan E, Zacchello F. Cx26 deafness: mutation analysis and clinical variability. F Med Genet 1999;36:82932 .

9 Denoyelle F, Weil D, Maw MA, Wilcox SA, Lench NJ, Allen-Powell DR, Osborn AH, Dahl HHM, Middleton A, Houseman MJ, Dodé C, Marlin S, Boulila-ElGaïed A, Grati M, Ayadi H, BenArab S, Bitoun P, Lina-Granade G, Godet J, Mustapha M, Loiselet J, El-Zir E, Aubois A, Joannard A, Levilliers J, Garabédian EN, Mueller RF, Gardner RJM, Petit C. Prelingual deafness: high prevalence of a $30 \mathrm{delG}$ mutation in the connexin 26 gene. Hum Mol Genet 1997;6:2173-7.

10 Zelante L, Gasparini P, Estivill X, Melchionda S, D’Agruma L, Govea N, Mila M, Della Monica M, Lutfi J, Shohat M, Mansfield E, Delgrosso K, Rappaport E, Surrey S, Fortina $P$. Connexin26 mutations associated with the most common form of non-syndromic neurosensory autosomal recessive deafness (DFNB1) in Mediterraneans. Hum Mol Genet 1997;6:1605-9.
11 Kelley PM, Harris DJ, Comer BC, Askew JW, Fowler T, Smith SD, Kimberling WJ. Novel mutations in the Smith SD, Kimberling WJ. Novel mutations in the (DFNB1) hearing loss. Am f Hum Genet 1998;62:792-9.

12 Estivill X, Fortina P, Surrey S, Rabionet R, Melchionda S, D'Agruma L, Mansfield E, Rappaport E, Govea N, Mila M, Zelante L, Gasparini P. Connexin-26 mutations in sporadic and inherited sensorineural deafness. Lancet 1998; 351:394-8.

13 Rabionet R, Zelante L, Lopez-Bigas N, D'Agruma L, Melchionda S, Restagno G, Arbones ML, Gasparini P, Estivill $X$. Molecular basis of childhood deafness resulting from mutations in the GfB2 (connexin 26) gene. Hum Genet 2000;106:40-4.

14 Abe S, Usami S, Shinkawa H, Kelley PM, Kimberling WJ. Prevalent connexin 26 gene (GFB2) mutations in Japanese. 7 Med Genet 2000;37:41-3.

15 Park HJ, Hahn SH, Chun YM, Park K, Kim HN. Connexin26 mutations associated with nonsyndromic hearing loss. Laryngoscope 2000;110:1535-8.

16 Kudo T, Ikeda K, Kure S, Matsubara Y, Oshima T, Watanabe $K$, Kawase $T$, Narisawa $K$, Takasaka T. Novel mutations in the connexin 26 gene (GJB2) responsible for childhood deafness in the Japanese population. Am $\mathcal{F} \mathrm{Med}$ Genet 2000;90:141-5.

17 Morell RJ, Kim HJ, Hood LJ, Goforth L, Friderici K, Fisher R, Van Camp G, Berlin CI, Oddoux C, Ostrer H, Keats B, Friedman TB. Mutations in the connexin 26 gene (GFB2) among Ashkenazi Jews with nonsyndromic recessive deafness. N Engl f Med 1998;339:1500-5.

18 Sobe T, Erlich P, Berry A, Korostichevsky M, Vreugde S, Avraham KB, Bonne-Tamir B, Shohat M. High frequency of the deafness-associated 167 delT mutation in the connexin 26 (GFB2) gene in Israeli Ashkenazim. Am f Med Genet 1999;86:499-500.

19 Brobby GW, Müller-Myhsok B, Horstmann RD. Connexin 26 R143W mutation associated with recessive nonsyndromic sensorineural deafness in Africa. $N$ Engl $\mathfrak{f}$ Med 1998;338:548-9.

20 Carrasquillo MM, Zlotogora J, Barges S, Chakravarti A. Two different connexin 26 mutations in an inbred kindred segregating non-syndromic recessive deafness: implications for genetic studies in isolated populations. Hum Mol Genet 1997;6:2163-72.

21 Lench NJ, Markham AF, Mueller RF, Kelsell DP, Smith RJH, Willems PJ, Schatteman I, Capon H, Van De Heyning PJ, Van Camp G. A Moroccan family with autosomal recessive sensorineural hearing loss caused by a mutation in the gap junction protein gene connexin 26 (GJB2). F Med Genet 1998;35:151-2.

22 Gasparini P, Rabionet R, Barbujani G, Melchionda S, Petersen M, Brondum-Nielsen K, Metspalu A, Oitmaa E, Pisano M, Fortina P, Zelante L, Estivill X, The Genetic Analysis Consortium of $G 7 B 2$ 35delG. High carrier frequency of the $35 \mathrm{delG}$ deafness mutation in European populations. Eur f Hum Genet 2000;8:19-23.

23 Storm K, Willocx S, Flothmann K, Van Camp G. Determination of the carrier frequency of the common GJB2 (connexin-26) 35delG mutation in the Belgian population using an easy and reliable screening method. Hum Mutat using an easy and

24 Lucotte G, Bathelier C, Champenois T. PCR test for diagnosis of the common GJB2 (connexin 26) 35delG mutation on dried blood spots and determination of the carrier frequency in France. Mol Cell Probes 2001;15:57-9.

25 Antoniadi T, Rabionet R, Kroupis C, Aperis GA, Economides J, Petmezakis J, Economou-Petersen E, Estivill X, Petersen MB. High prevalence in the Greek population of the 35 delG mutation in the connexin 26 gene causing prelingual deafness. Clin Genet 1999;55:381-2.

26 Scott DA, Kraft ML, Carmi R, Ramesh A, Elbedour K, Yairi Y, Srisailapathy CRS, Rosengren SS, Markham AF, Mueller RF, Lench NJ, Van Camp G, Smith RJH, Sheffield VC. Identification of mutations in the connexin 26 gene that cause autosomal recessive nonsyndromic hearing loss. Hum Mutat 1998;11:387-94.

27 Green GE, Scott DA, McDonald JM, Woodworth GG, Sheffield VC, Smith RJH. Carrier rates in the midwestern Sheffield VC, Smith RJH. Carrier rates in the midwestern
United States for GJB2 mutations causing inherited deafness. $7 A M A$ 1999;281:2211-16.

28 Morral N, Bertranpetit J, Estivill X, Nunes V, Casals T, Gimenez J, Reis A, Varon-Mateeva R, Macek MJ, Kalaydjieva L, Angelicheva D, Dancheva R, Romeo G, Russo MP, Garnerone S, Restagno G, Ferrari M, Magnani C, Claustres M, Desgeorges M, Shwartz M, Schwarz M, Dallapiccola B, Novelli G, Ferec C, de Arce M, Nemeti $M$, Kere J, Anvret M, Dahl N, Kadasi L. The origin of the major cystic fibrosis mutation (delta F508) in European populations. Nature 1994;7:169-75.

29 Serre JL, Simon-Bouy B, Mornet E, Jaume-Roig B, Balassopoulou A, Schwartz M, Taillandier A, Boue J, Boue A. Studies of RFLP closely linked to the cystic fibrosis locus throughout Europe lead to new considerations in populations genetics. Hum Genet 1990;84:449-54.

30 Romeo G, Devoto M, Galietta LJV. Why is the cystic fibrosis gene so frequent? Hum Genet 1989;84:1-5. 